KRUNOSLAV LUČIĆ

Faculty of Humanities and Social Sciences University of Zagreb

\section{Stylistic heritage and tendencies in contemporary Croatian cinema}

\begin{abstract}
Lučić Krunoslav, Stylistic heritage and tendencies in contemporary Croatian cinema. „Images” vol. XXIII, no. 32. Poznań 2018. Adam Mickiewicz University Press. Pp. 57-76. ISSN 1731-450X. DOI 10.14746/i.2018.32.06.

This paper focuses on the diverse stylistic heritage and various tendencies in Croatian cinema of the 1990s and 2000s. Since many film scholars accentuate the discontinuity between contemporary Croatian cinema and that from the Yugoslav period, the paper points to continuities in the stylistic trends of both periods. The paper also analyzes two major stylistic configurations - classical and modernist - focusing on different variants of both aesthetic orientations. Variants of cinematic classicism (reduced and excessive classical style) are exemplified by the films of Krešo Golik and Fadil Hadžić, and by the films of Dalibor Matanić and Zrinko Ogresta from the contemporary period. On the other hand, variants of cinematic modernism (realist and psychological) are exemplified by the films of Vatroslav Mimica and Ante Peterlić from the 1960s, and in the contemporary period by the films of Zrinko Ogresta and Lukas Nola.
\end{abstract}

KEYwORDs: Croatian cinema, 1990s-2000s, Yugoslav period, film stylistics, classical film style, modernist film style, variants of film style

In an effort to analyze and explain the history of contemporary, post-1990s Croatian cinema in comparison to its earlier period as part of Yugoslav film culture, many film scholars, for example Škrabalo,[1] Turković and Majcen, [2] and Gilić, [3] have pointed to a strong transition or historical and aesthetic breakdown that occurred in 1990/1991. From that perspective, Croatian cinema of the early 1990 os divorced itself from its Yugoslav heritage and started to develop in its own right. This historical discontinuity was visible in the low quality and aesthetic poverty of Croatian cinema up until the mid-1990s, and also through a tendency to neglect the cinematic style found in mature classical and modernist works from earlier film periods. But scholars have also pointed out that since the early years of Croatian cinema, the concept of historical continuity, at least in its typological form with its propagandistic war motifs, was similar to the early Yugoslav cinema of the 1940s.

Yet, the concept of cinematic and historical continuity between the two periods in Croatian film history is also visible when tracing the activity of the directors who worked in the Yugoslav and Croatian states. Not only were certain directors active in both states, but they also
[1] I. Škrabalo, Hrvatska filmska povijest ukratko (1896-2006), Zagreb 2008, p. 167.

[2] H. Turković, V. Majcen, Hrvatska kinematografija: povijesne značajke, suvremeno stanje, filmografija (1991-2002), Zagreb 2003, p. 42.
Images vol. XXIII/no. 32

Poznań 2018
ISSN 1731-450X

\section{Introduction}

[3] N. Gilić, Uvod u povijest hrvatskog igranog filma, Zagreb 2010, p. 141; Idem, Filmski medij, in: Uvod u medije, ed. Z. Peruško, Zagreb 2011, pp. 87-108. 
continued to develop and actualize their distinctive cinematic styles throughout their long lasting careers. This is visible in the post $1990 \mathrm{os}$ films of Ante Babaja such as The Stone Gate (Kamenita vrata, 1992), Zoran Tadić with Eagle (Orao, 1990) and The Third Woman (Treća žena, 1997), Krsto Papić with A Story from Croatia (Priča iz Hrvatske, 1991), Zvonimir Berković with Countess Dora (Kontesa Dora, 1993), and Tomislav Radić with What Iva Recorded (Što je Iva snimila 21. listopada 2003. (2005) and Kotlovina (2011), with Radić being a prime example of a modernist author who continued to develop his unique documentary-like poetics from the 1970s.[4]

A continuity of style in contemporary Croatian cinema is also visible in the context of distinctive aesthetic alternatives that were already developed and established in Yugoslav cinema. Croatian film scholar Hrvoje Turković[5] observed that Yugoslav cinema balanced between popular/populist and elitist aesthetics, with many variants found, while Nikica Gilić[6] observed the same trend in the context of post-199os Croatian cinema, though he qualified these tendencies as genre- or modernist-oriented. The point of this comparison is that when certain stylistic alternatives are established and developed they can always become aesthetic dispositions that can be repeated, complicated and/or rejected depending on different factors.

It is also important to point out that while the general understanding of the stylistic tendencies in the history of Croatian cinema goes along with the concept of the prevalence of the modernist alternative, as observed by Turković,[7] primarily through the influence of genre film criticism and the valuing of classical cinema technique from the $1960 \mathrm{~s}$ onwards, Croatian cinema was (statistically) more saturated by genre and classical poetics. [8] Bearing in mind these things, the goal of this paper is to trace the stylistic heritage of post-1990s Croatian cinema between these two stylistic alternatives, with its many variants or types, and to examine which contemporary films have followed their aesthetic patterns.

The concepts of "heritage" and "tendencies" indicated in the title of the paper do not imply some direct connection between, for example, modernist cinema of the 1960 os and similar cinema of the 2000 , but merely implies reflections of or follow ups of those earlier stylistic trends. In that context, and unlike the concept of the "film movement" or "film school", film tendency implies some form of trans-historical

[4] Idem, Dokumentarističke tehnike otpora u igranom filmu i rani filmovi Tomislava Radića, in: Otpor. Subverzivne prakse u hrvatskome jeziku, književnosti $i$ kulturi, eds. T. Pišković, T. Vuković, Zagreb 2014, pp. 9-20.

[5] H. Turković, Filmska opredjeljenja, Zagreb 1985, p. 16.

[6] N. Gilić, Filmski medij..., p. 104.

[7] H. Turković, Film: zabava, žanr, stil, Zagreb 2005 , pp. $276-277$.
[8] B. Kragić, Izazovi "Amerike" u hrvatskom filmu i pisanju o filmu - esej o postupnoj realizaciji naslovne metafore", in: Prešućeno, zabranjeno, izazovno u hrvatskoj književnosti i kazalištu, eds. N. Batušić et al., Zagreb 2007, p. 530. J. Pavičić, Usiljena učitavanja: filmska i književna kritika o hrvatskoj žanrovskoj proizvodnji, "Hrvatski filmski ljetopis" 2000, no. 22, pp. 35-37. 
stylistic orientation that is at the disposition of the author, who tries to follow it or use some variant of it,[9] or use an alternative for that matter. Also, by film style, I am referring to the broad spectrum of choices that the author can use to develop a recognizable film structure. As pointed out by Robinson [10] (1985: 227), style in general is "a way of doing certain things", and film style is best understood as a way of structuring film narrative (when dealing with narrative cinema) through the manipulation of different techniques (e.g. framing, scale, angle, editing, sound etc.) and narrative elements (e.g. characters, events, motifs, objects, causal connections etc.).[11] That is, style refers to the specific configuration of the analyzed film.[12]

In that context, the paper will focus on describing and explaining not only stylistic tendencies in contemporary Croatian cinema by tracing its heritage from earlier cinema periods, but will also focus on two main styles and their subtypes: classical and modernist style understood as general stylistic options.[13] Variations of these two general styles will be explained in terms of their extremes. I will presuppose that classical film style has an ideal form, found in a so-called ordinary or typical film, [14] and that variants develop in two directions: by reducing classical properties or by developing them to an extreme (so-called excessive classical style). On the other hand, since modernist style cannot be understood in the same fashion, I will simply analyze its two distinctive orientations: one that is structured in realist terms, and another that is structured in psychological terms with some overlap between the two.

It is also worth mentioning that this paper tries to fill a gap in our understanding of the full scope of contemporary Croatian cinema, since many recent studies [15] have focused more on purely thematic criticism, representational practices and/or ideological criticism, neglecting an important trend in contemporary film studies with an explicit stylistic orientation.

As classical and modernist cinema developed during the pre1990 os period, they became permanent stylistic options that could be

Stylistic heritage of Croatian cinema articulated in later periods of Croatian cinema. These two stylistic tendencies also implied that once they were fully developed, they could be realized in different stylistic directions. This means that both classical and modernist tendencies could vary depending on artistic and/or pro-

[9] H. Turković, Nacrt filmske genologije, Zagreb 2010, p. 139.

[10] J.M. Robinson, Style and personality in the literary work, "The Philosophical Review" 1985, no. 2 (94), p. 227.

[11] There are some serious criticism and skepticism addressed to stylistic research in general, for example, by Gray (1973), but we can see that it can still produce interesting and useful results.
[12] H. Turković, Film: zabava..., pp. 240-242. [13] J. Robinson, 1984, General and individual style in literature, "The Journal of Aesthetics and Art Criticism" 1984, no. 2 (43), pp. 147-158.

[14] D. Bordwell, J. Staiger, K. Thompson, The Classical Hollywood Cinema. Film Style \& Mode of Production to 1960, London 1999, p. 10.

[15] For example Lučić 2016, Vidan 2011, Vidan 2013, Pavičić 2010, Hirschfeld 2011, Simić 2006, Vojković 2006, Laćan 2015, Moss 2008, Rucker-Chang 2012. 
duction sensibilities and inclinations. In that context, classical cinema was developed in its ideal form during the 1950s, especially in works by Branko Bauer, while modernist cinema was strongly articulated during the 196os, almost simultaneously with European modernist trends. This Croatian cinema of the 1960 s also qualified as auteur cinema, [16] with its basis in open directorial intervention and expression. A key figure in this context was Vatroslav Mimica, whose modernist approach to cinematic style would later be visible in the films of Lukas Nola.

As stated in the introduction, both stylistic tendencies functioned as an artistic background for later, post-199os stylistic articulations, and we can see that different stylistic variants of both tendencies were already present during the Yugoslav period of Croatian cinema. In the context of classical stylistic tendencies, we can observe both an inclination to reduce classical features in this conventional stylistic configuration, and a tendency to develop it in an excessive way. Classical film style is commonly understood as a discursive option where relevant story information is presented in a clear and economical manner, that is, where film technique functions as a tool for helping the spectator to understand the film narrative, which usually consists of a protagonist with a clear-cut goal and motivation, and an inclination to resolve a problem posited in earlier parts of the film. As Bordwell[17] has stated, we "can define classical narration as a particular configuration of normalized options for representing the fabula and for manipulating the possibilities of syuzhet and style". Another important aspect of the classical style is a standardized use of different stylizations (stylistic deviations) in places where there is a need for additional regulation of the story's events and conflicts, that is, dramatic accents or transitions. In this context, classical narrative style is most commonly understood in a homogeneous way, and very few scholars have observed that it can be realized in a heterogeneous way.[18]

Keeping this in mind, we can see how pre-1990s Croatian films balanced between the two previously-mentioned classical stylistic options. For example, even though the film Borders (Razmeda, 1973) by Krešo Golik seems to present a clear-cut narrative about the struggles in life of its main character and his attempt to deal with ongoing problems, the opening of the film points toward a reducing of the classical stylistic paradigm. Conventional exposition in classical cinema usually employs the strategy of introducing the main character, his life setting and the potential problems that he will try to resolve. The opening of Borders also employs this strategy but focuses extensively on long-take presentation of the banal, daily morning routine of the main character. Extensive, long presentations of this kind of activity are usually shot in

[16] H. Turković, Filmska opredjeljenja..., p. 46.

[17] D. Bordwell, Narration in the Fiction Film, London and New York 2008, p. 156.

[18] One of the scholars who accentuated this feature of classical cinema is Kragić (B. Kragić, Klasični stil u historiografijama hrvatskoga filma, in: 6o godina Festivala igranoga filma u Puli i hrvatski film, eds. N. Gilić and Z. Vidačković, Zagreb 2013, pp. 81 and 97) who observed that it can have many different articulations. 
a more economical and narratively functional manner by eliminating certain phases of these activities and showing the viewer only selected elements. By extending the plot beyond what is narratively relevant, Golik here is showing the stylistic option of reducing the classical style through a (paradoxically) redundant narration.

A somewhat different strategy is employed in another Golik film, I Have Two Mothers and Two Fathers (Imam 2 mame i 2 tate, 1968). Here the reduction of the classical style is achieved through a weakening of the causal relations between the presented events and by focusing the narrative perspective through a little boy, Đuro. Even though Đuro is a focus of the narration he lacks a clearly formulated goal and does not influence the story's action. In an ideal classical form the protagonist would have a more significant impact on the story's action. In this context, most of the events presented are not a result of the plot's development, but of circumstances that obtrude on the little boy and employment of the logic of ritual repetition seen in Sunday family meals that he has to attend.

A different stylistic tendency can be observed in another of Golik's films, The Girl and the Oak (Djevojka i hrast, 1955). Here the overall narrative is not weakened, but enriched by adding a stylized layer to the story. Employing a strategy of visual stylization retards the flow of story information and functions as artistic excess that lacks any obvious narrative significance. This is visible in a series of shots exemplified in Fig. 1, where the use of a backlight accentuates the shadow of the main female character, Smilja, for purely artistic purposes. A similar strategy can be seen in the film Alphabet of Fear (Abeceda straha, 1961) by Fadil Hadžić, where the usage of unusual camera angles functions in the same way. Even though Hadžić employs this visual extravagance in the film's climax to accentuate the drama of the ongoing action through low and high angle shots, discontinuities in editing, and chiaroscuro lighting (see Fig. 2), this strategy is quite commonly used in the classical style, since it functions as a means to support the narrative. But when a similar presentational strategy is used beyond its narrative functionality, it can be understood as visual excess that is employed for its own sake (see Fig. 3).

On the other hand, and unlike classical cinema, modernist style has always been recognized as a heterogeneous phenomenon. Since it is commonly understood as an expression of a strong authorial conscience, it is presumed that it can be realized in many ways. For example,
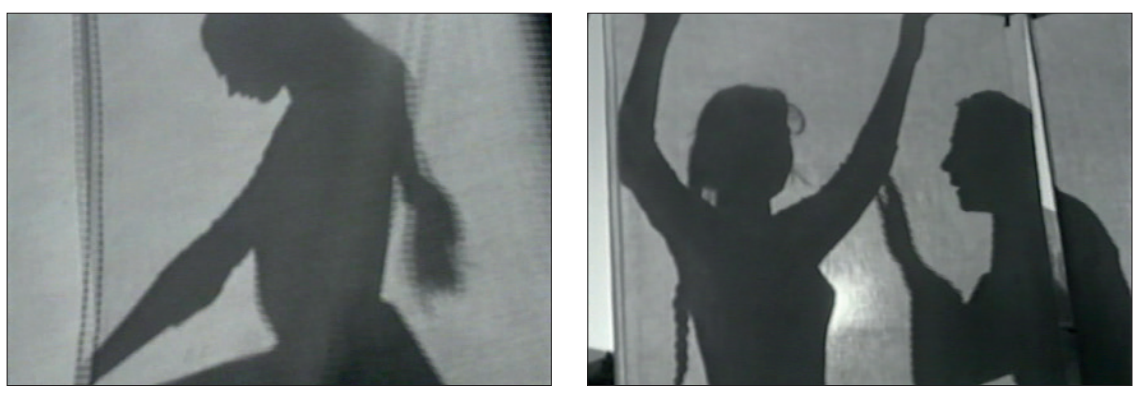

Fig. 1. The Girl and the Oak (Djevojka i hrast, 1955) by Krešo Golik 

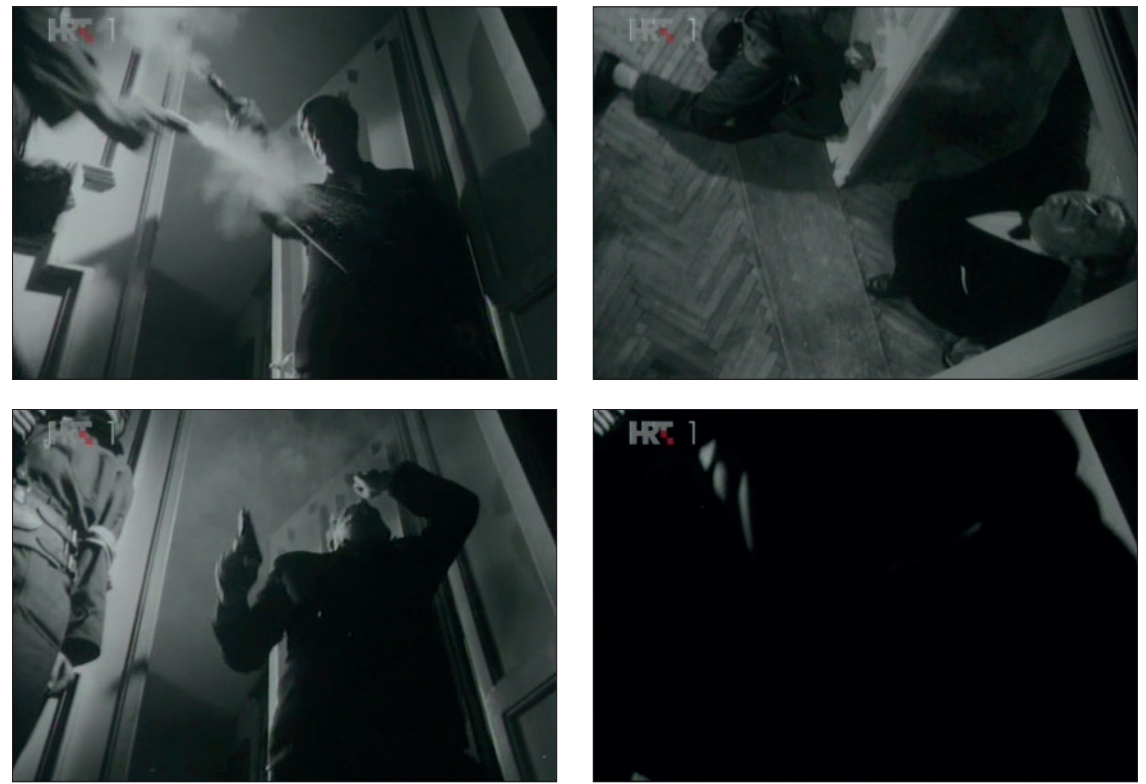

Fig. 2. Alphabet of Fear (Abeceda straha, 1961) by Fadil Hadžić
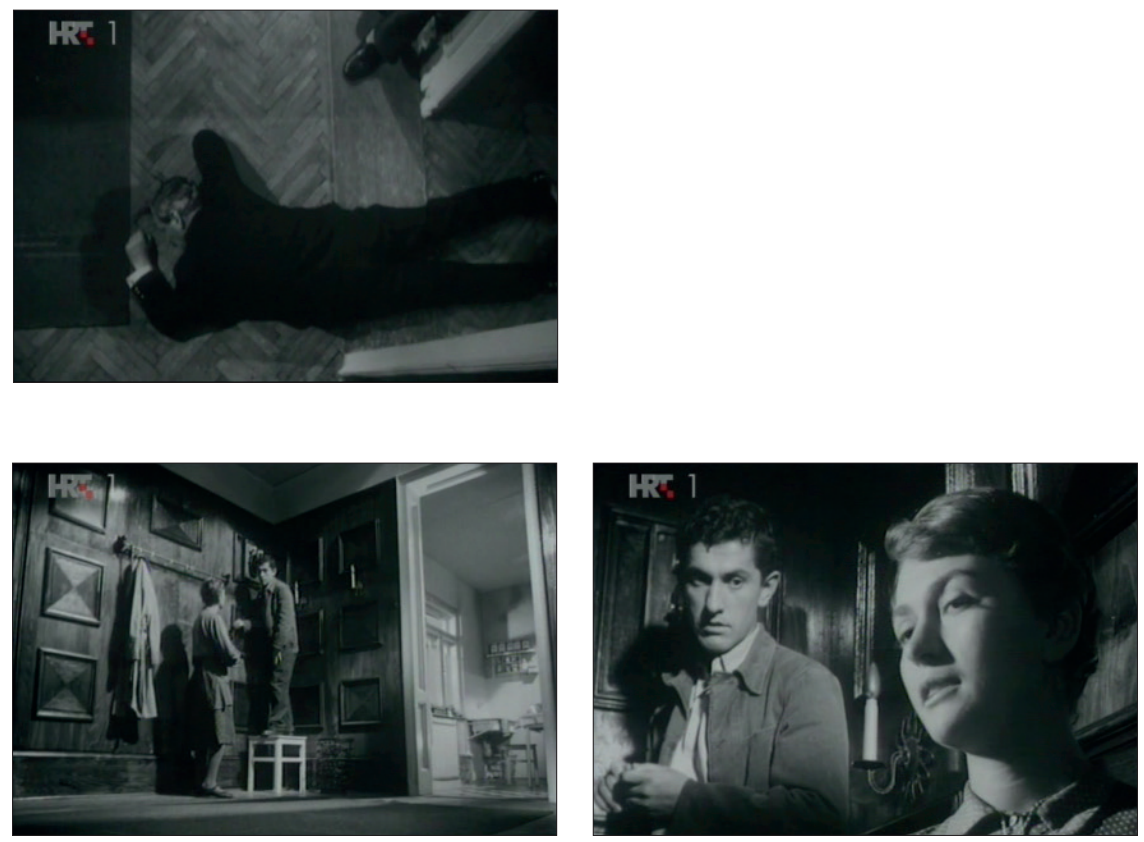

(Abeceda straha, 1961)
(Alphabet of Fear by Fadil Hadžić

Bordwell[19] recognized three types of what he called art-cinema as an alternative to classical storytelling: 'objective' realism, 'expressive' or subjective realism, and narrational commentary (through external authority). Turković[20] observed a similar tendency in Yugoslav cinema of the 1960s, but offered different qualifications: namely discrete, anti-aesthetical and aesthetical modernism. Even though these typologies are not equivalent, we can observe that modernist cinema can also balance between focusing on everyday, banal events and the rituals of its characters, and on their subjective mental states, frequently

[19] D. Bordwell, Narration in the Fiction Film..., [20] H. Turković, Filmska opredjeljenja..., p. 46. p. 205. 
presented in a radical visual form. We can qualify the first as a type of realist modernist style and the second as a psychological modernist style with much overlap.

For example, the film Accidental Life (Slučajni život, 1969) by Ante Peterlić is a good variant of the realist style realized in modernist terms, since its narrative is reduced to depicting the everyday life of a character named Filip without ever accentuating his motivations or a goal. The bleak everydayness of the character is additionally enriched by a typical modernist strategy where important narrative events are presented from unfavorable perspectives, focusing, instead, on narrative marginality. Also, extensive employment of poetic, narratively redundant sequences (for example rowing on the Sava River) are so extreme that talking about this film in classical terms would be quite odd.

Unlike this example, the film Monday or Tuesday (Ponedjeljak ili utorak, 1966) by Vatroslav Mimica goes to another extreme. It also depicts the ritual everydayness of a character, Marko, but here the focus of the presentation is shifted towards his mental states, desires, fantasies, fears, daydreams, recollections etc. This is already visible in the opening of the film, where the simple narrative action of a morning awakening is narratively prolonged (through time-expansion) by saturating the sequence with highly stylized shots of Marko's dreams (see Fig. 4).
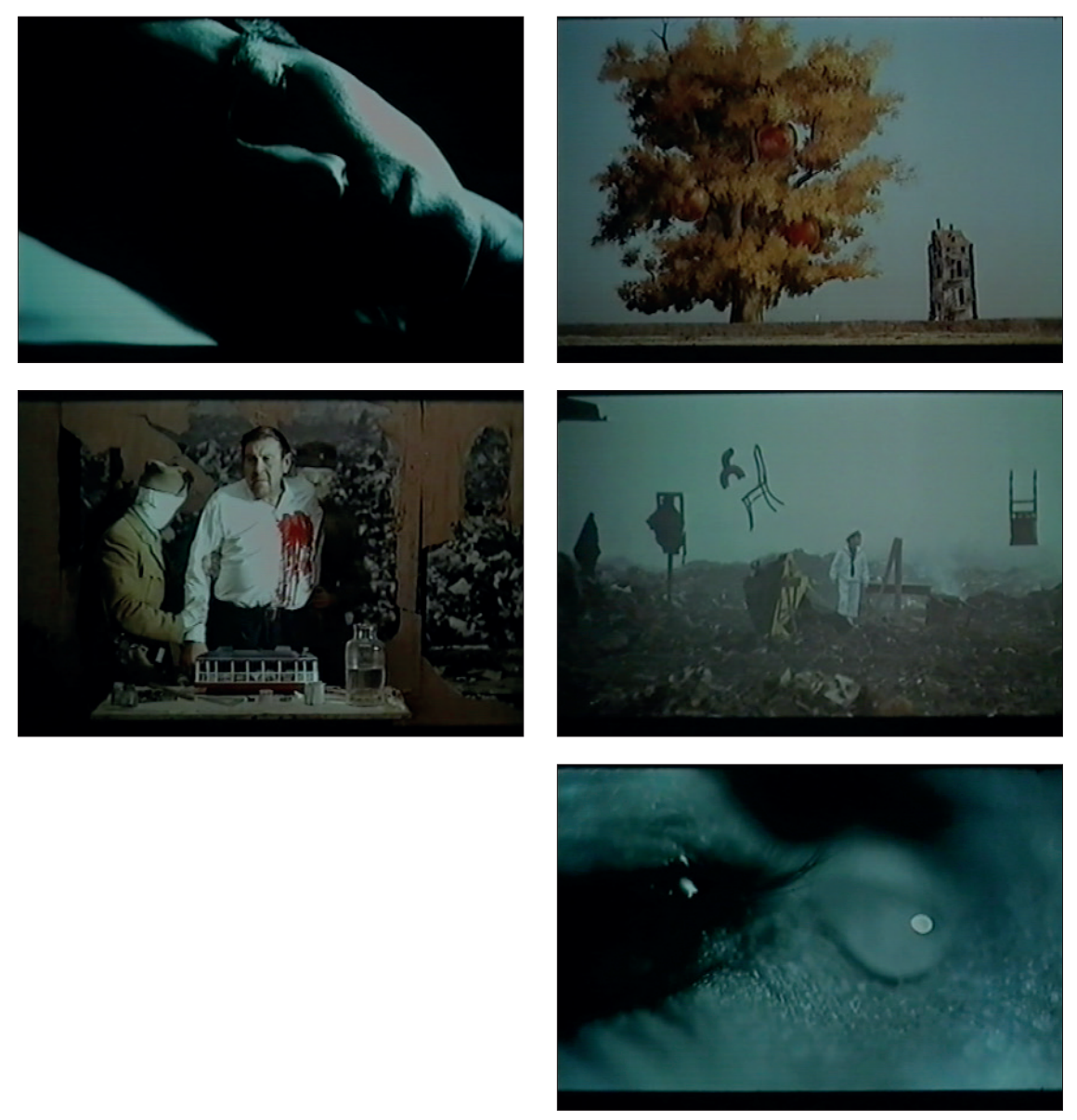

Fig. 4. Monday or Tuesday (Ponedjeljak ili utorak, 1966) by Vatroslav Mimica 
In subsequent sections of this paper, I will show how all these variants of classical and modernist cinema were articulated in contemporary Croatian cinema through the works of Dalibor Matanić, Ognjen Sviličić, Zrinko Ogresta, Arsen Anton Ostojić, Lukas Nola and others.

\section{Stylistic tendencies of a classical film in contemporary Croatian cinema}

Bearing in mind the multidirectional tendencies present in the Yugoslav period of Croatian cinema, we can observe similar stylistic patterns in the contemporary state of affairs. As already stated, the first half of the 1990s was an example of a somewhat regressive cinematic style,[21] echoing the primitive form of the classical style of Yugoslav cinema up until the 1950s. Croatian cinema soon articulated its style in full classical scope and simultaneously branched out in various classical style directions.

One such stylistic tendency was, as has already been mentioned, a reduced classical style. This type of style includes the weakening of causal connections between the events presented, marginal motivation of the characters' actions, and retardation of the film narration with often uninteresting and narratively nonfunctional scenes.[22] In one context, this stylistic tendency to slow the film's tempo and focus more on narrative digressions instead of clear, goal-oriented action, was qualified as an example of late classical cinema.[23] From this perspective, an orientation toward weakening the ideal form of classical cinema can be seen in some works by Zrinko Ogresta and Ognjen Sviličić. Even though some scholars, like Kragić, [24] describe their films as examples of a pure classical style, I will treat them as authors of this reduced type of cinematic classicism (at least some of their films).

An interesting example of such a tendency is the case of Ogresta, on whom scholars have varying views. For example, Gilić[25] describes Ogresta's film Washed Out (Isprani, 1995) as art cinema, thus moving it towards the modernist tendency. Gilić[26] in general recognizes that Ogresta's films follow the tradition of auteur cinema with strong artistic interventions. Škrabalo,[27] in turn, describes Ogresta's film Red Dust (Crvena prašina, 1999) as "aesthetically pretentious", thus also placing it in the realm of art cinema genre with obvious modernist elements. As we can see from these insights, his films are not understood as classical in the purest sense of the term.

On the other hand, Ogresta's film Washed Out can also be understood as a good example of the reduced classical style tendency. The
[21] J. Pavičić, Trendovi hrvatskog filma, "Hrvatski filmski ljetopis" 1997, no. 11, pp. 3-8.

[22] K. Lučić, Filmski stil: teorijski pristup i stilistika hrvatskog igranog filma, Zagreb 2017, p. 169.

[23] B. Kragić, Neke tendencije klasičnoga filma: tri eseja, Zagreb 2017, p. 27.

[24] B. Kragić, Hrvatski film nakon 1990. - prijedlog stilske klasifikacije, "Sarajevske sveske" 2008, no. 19-20, p. 236.
[25] N. Gilić, New Croatian Cinema: Literature and Genre in the Post-Yugoslav Era, in: Small Cinemas in Global Markets, eds. L. Giukin, J. Falkowska and D. Desser, Lanham, Boulder, New York, London 2015, p. 161.

[26] N. Gilić, Uvod u povijest..., pp. 144-145.

[27] I. Škrabalo, op.cit., p. 175. 
film's narrative is focused on two characters, Zlatko and Jagoda, who in the setting of postwar Zagreb try to find a place to sexually consummate their love. But even though this is, at first glance, the central tendency of the film's narrative, it is placed at the margins of the story and is not followed in detail. The film's narrative is more focused on depicting the existential background of Croatian postwar society and its negative impact on the characters than on exploiting well-defined goals or the motivations of key narrative figures. So, instead of focusing on a character's goals as a benchmark of classical narration, the film depicts the existential state of affairs of a broad spectrum of different characters loosely connected with the protagonists. The film very often also slows down its narrative progress through the implementation of non-functional digressions, that is, by focusing on the psychological state of the female character Jagoda through long takes of her wandering the empty city streets and observing the everyday actions of people. These film sequences are poetic in nature and do not advance the film's narrative.

The motif of the unchanged narrative situation in which the characters are trapped is also advanced through use of dramatic conflict in a reduced and non-classical manner. In the classical film style conflict is usually employed in order to advance the ongoing action and has a direct causal influence on the narrative situation. But in this film every conflict is treated as an isolated event that does not change anything in the life of the characters. The reduced element of the classicism of this film is also visible in the use of narratively non-functional diegetic inserts that would otherwise be used as elements of narrative complication. Thus, for example, multiple shots of the fan on the wall in the local bar (where Jagoda's brother is drinking) function as visual decorations and as an element of unnecessary narrative and time retardation.

A similar tendency towards reducing the classical style of the film is visible in another of Ogresta's works, Red Dust. Here the central narrative action is more clearly developed, but the protagonist Luka Crnjak (Crni) is reduced to a figure who tries to cope with events that he cannot change. The overall focus of the film is oriented more toward depicting the deteriorating values of Croatian prewar and postwar society than on following the events that result from the protagonist's goals.

In a similar fashion, some scholars have observed that the aforementioned director Ognjen Sviličić also exploits this type of reduced classicism in his films. For example, Škrabalo[28] pointed out that his film Sorry for Kung Fu (Oprosti za kung fu, 2004) is "minimalistic structured", while Armin's (2007) style has been described as "restrained". On the other hand, Šakić[29] uses a similar description (of stylistic minimalism) for these two of Sviličićs films, but contextualizes them in modernist terms. Even though this type of ambivalent stylistic description can be puzzling, it is understandable since every time classical

[28] Ibidem, pp. 231-232.

[29] T. Šakić, Modernizam u hrvatskom igranom filmu, Zagreb 2016, p. 163. 
film reduces its properties using elements that are usually connected to its counterpart, it can also be understood as modernist.[30]

The films of Dalibor Matanić provide a good example of another tendency in contemporary Croatian cinema. They often employ a classical story format with clear narrative development, but enrich it with exaggerated use of film technique. Kragić summarized this type of stylistic orientation in the following way: "unlike populist films which underscore style on behalf of the story, these films accentuate the style, but only to strengthen the importance of the story." [31] Even though Kragić labeled this type of style as postmodernist, it can be argued that it also applies to what I have called the excessive classical film style. A similar understanding of this type of cinematic classicism was advanced by Bordwell[32] when talking about the decorative or ornamental functions of style in a classical film. In this context, film technique is often used in order to exceed its purely narrative function which, in the standard form, enables the spectator to easily follow the story's progress and identify key aspects of the film's narrative (characters, action and setting).

Matanićs film Fine Dead Girls (Fine mrtve djevojke, 2002) is a prime example of this type of excessive use of film technique where there is no narrative justification for its employment. Even though the film tells a straightforward story about a lesbian couple which undergoes discrimination in postwar Zagreb, Matanić often uses unusual camera angles, camera movements, distance and mise-en-scene solutions that stand on their own right in the stylistic configuration of his work. For example, when the lesbian couple is moving into their new rented apartment, the interaction between them and the landlord Olga is presented in a highly stylized fashion, which prevents the viewer from having the best possible viewpoint of the ongoing situation. More conventional classical cinema would minimize the use of film technique in order to enable the viewer to follow the action, but Matanic uses a rich spectrum of techniques to present this simple situation. He uses different cinematic extremes, such as a combination of extreme closeups followed by an extreme long shot, unmotivated low angle framing accompanied by extreme horizontal angle shifting (across the line of action, see Fig. 5). This type of style goes against more conventional uses of film technique and can be understood as a process of visual, non-narrative stylization.

Matanić used similar but less extreme excesses in his earlier film The Cashier Wants to Go to the Seaside (Blagajnica hoće ići na more, 2000), while his later film 100 Minutes of Glory (100 minuta Slave, 2004) about the female painter Slava Raškaj went a step further in a stylized

[30] This is also the case with some films by Branko Schmidt, for example Metastases (Metastaze, 2009) and Vegetarian Cannibal (Ljudožder vegetarijanac, 2012).
[31] B. Kragić, Hrvatski film nakon 199o..., p. 237.

[32] D. Bordwell, Poetics of Cinema, New York, London 2008, pp. 378-379. 

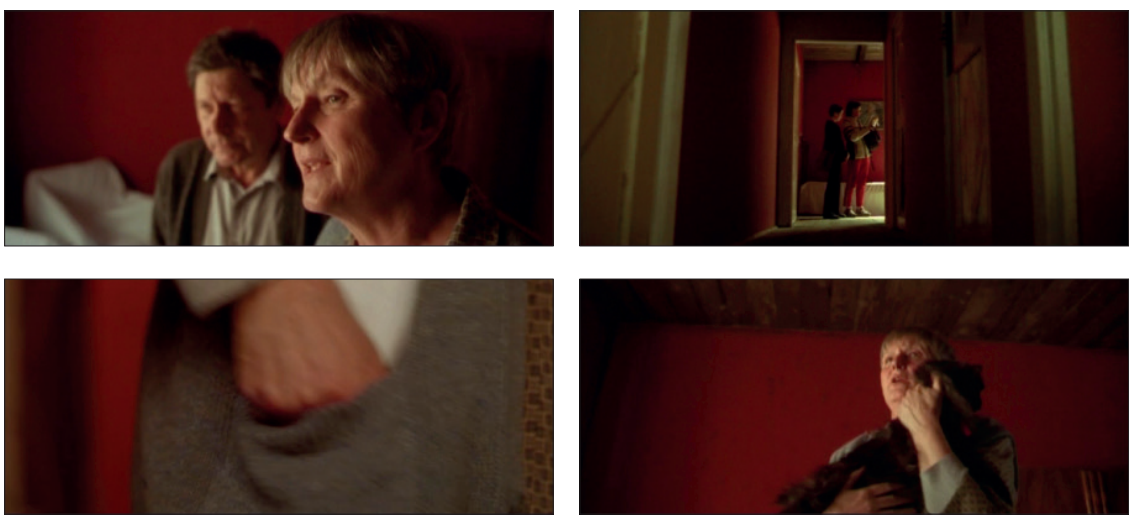

Fig. 5. Fine Dead Girls

(Fine mrtve djevojke, 2002)

by Dalibor Matanić

direction. The beginning of this film exemplifies this excessive stylistic tendency through the use of extreme close-ups and visually extreme mobile framing accompanied by the use of discontinuity editing (see Fig. 6). Even when Matanić uses the camera's movement to comment on ongoing events, he employs it so often and in such an extreme way that it looks like it is used in its own right, making it seem aesthetically self-sufficient. This happens in a scene where a forward tracking shot through an empty corridor is used to anticipate an important event (Slava's parents attacking her for her love affair with her mentor Bela Čikoš [Csikos], see Fig. 7). Even though this stylistic approach has a narrative function, it is used in a manner that is visually extravagant and part of the overall excessiveness of the film.
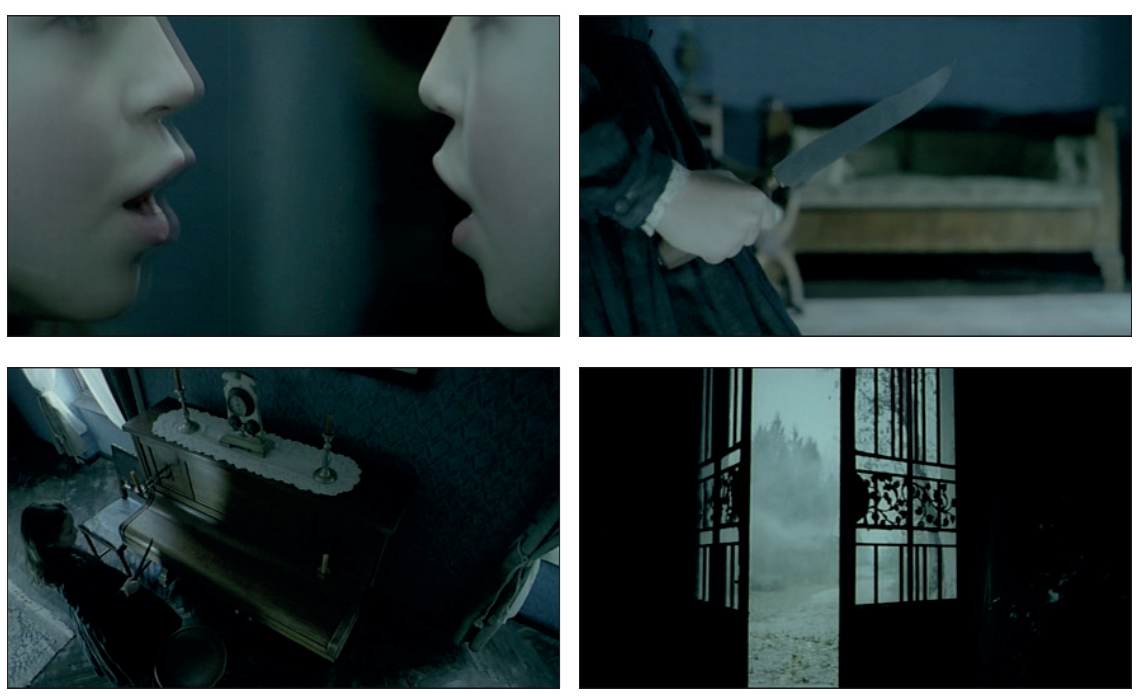

Fig. 6. 100 Minutes of Glory (10o minuta Slave, 2004) by Dalibor Matanić

A somewhat different stylistic tendency can be observed in the film Behind the Glass (Iza stakla, 2008) by Zrinko Ogresta. This film balances between strong visual excess and reduced narrative development. While the narrative is reduced to sketches of the everyday (work and love) problems of the protagonist Nikola, ending with a deus ex machina narrative resolution (the death of his mistress), the visual 
Fig. 7. 100 Minutes of Glory (10o minuta Slave, 2004) by Dalibor Matanić
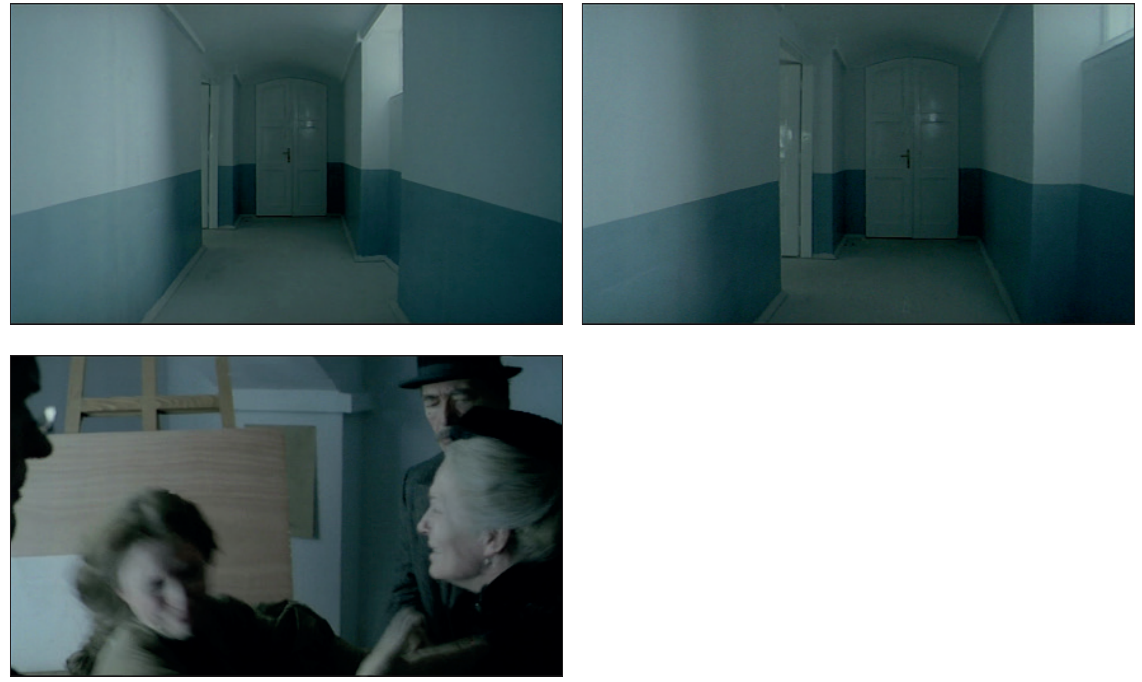

configuration develops along the line of a strong authorial commentary. This is already visible from the title of the film, which denotes two things: it metaphorically signifies the other, negative, hidden side of the protagonist's life, something behind his public mask, while in a literal sense it signifies the perpetual presentation of characters behind some sort of obstacle. Thus, when we see Nikola and his wife arguing in their apartment, the whole scene is shot with the camera positioned outside their apartment, literally "behind the glass", and additionally divides them by means of a vertical obstacle in the mise-en-scene (see Fig. 8). This type of presentation not only comments on the ongoing situation, but (since it is employed consistently through the film) also functions as a stylistic pattern in its own right, thus exceeding the pure narrativity of its use.[33]
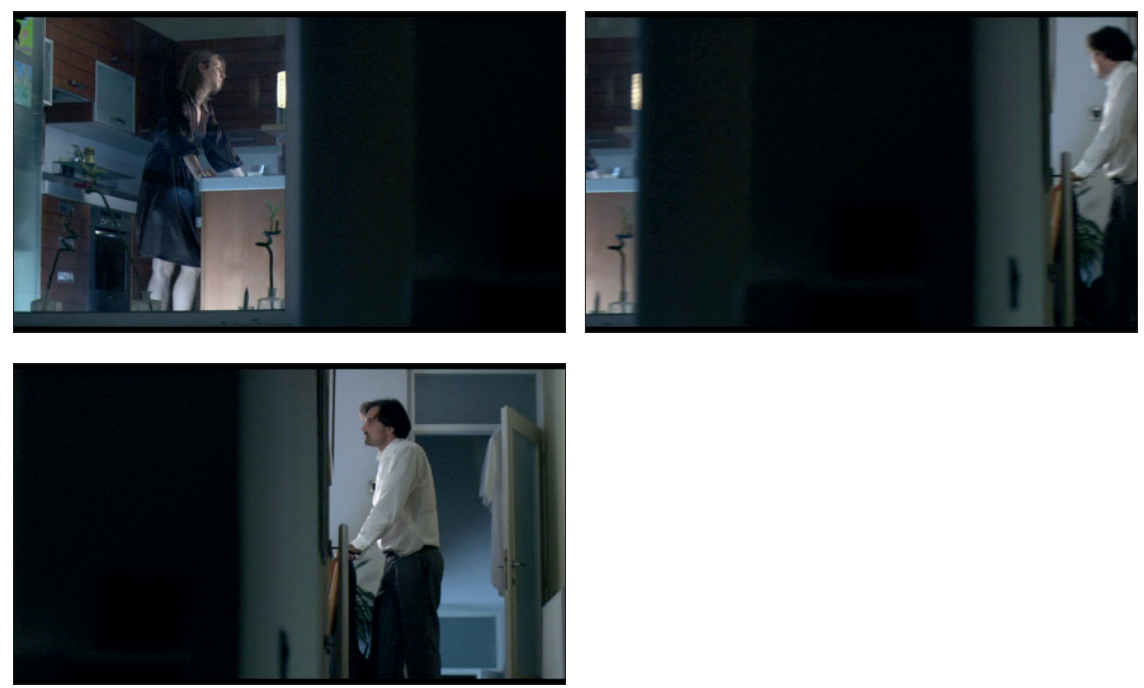

sical form. That is, it can be qualified, in accordance with Kovács's (2007: 61, 64) terminology and distinctions, as a classical art cinema.
[33] We have to bear in mind that while this film modernist expression, it is still structured in a clas-
Fig. 8. Behind the Glass (Iza stakla, 2008) by Zrinko Ogresta 
Contrary to the situation in the 1980 os when it was necessary to point out that classical films were artistically important and when the interpretative frame of reference was still leaning toward the modernist paradigm,[34] the post-199os situation was quite different. As some scholars have observed, modernist cinema ceased to be the dominant paradigm of film production and interpretation.[35] In this classically and genre-oriented context, directors who stood out as an examples of modernist film style included Lukas Nola and, in some cases, the aforementioned Zrinko Ogresta. Nola's films were especially understood as clear cases of the modernist stylistic tendency, echoing the approach of earlier, 1960s authors like Vatroslav Mimica.[36] But reflections of this modernist tendency was, according to Škrabalo, [37] also a permanent feature of at least one orientation in post-199os cinema.

As indicated earlier, there is the possibility of the coexistence of many classical film styles; the same holds true for modernist cinema, which is usually articulated in two directions. One being of a realist tendency, and the other, a psychological tendency.

Although Ogresta's films have been described as examples of auteur cinema, [38] and thus close to modernist expressions, only some of his films are actually modernist in their orientation. A good example of a realist type of modernist cinema is his film Here (Tu, 2003), described by Škrabalo[39] as "having a very modern structure", in part through its mosaic narrative form, which is often understood as an important feature of cinematic modernism.[40] Also, since this Ogresta's film is focused on describing the everydayness of different and mutually unconnected characters with a simple, unintrusive visual approach, it functions as an example of the realist type of cinematic modernism. Because of its use of documentary film techniques, this (sub)type of modernist cinema also relates to Tomislav Radić's film What Iva Recorded (Što je Iva snimila 21. listopada 2003., 2005)[41] and Kotlovina (2011), and some scholars contextualized these films in a modernist paradigm [42] even though they are still classical in how they develop their story form.

[34] H. Turković, Film: zabava..., pp. 276-277.

[35] B. Kragić, Hrvatski film nakon 1990..., p. 237; idem, Izazovi "Amerike" u hrvatskom filmu..., p. 534. J. Pavičić, Usiljena učitavanja: filmska..., op. cit., pp. 35-37. J. Pavičić, Trendovi hrvatskog filma..., pp. 3-8.

[36] N. Gilić, Tragovi modernizma 1960-ih u novijem hrvatskom igranom filmu, in: Komparativna povijest hrvatske književnosti. Zbornik radova XII. Istodobnost raznodobnog. Tekst i povijesni ritmovi, eds. C. Pavlović, V. Glunčić-Bužančić and A. Meyer-Fraatz, Split-Zagreb 2010, p. 422.

[37] I. Škrabalo, op.cit., pp. 213-214.

[38] N. Gilić, Uvod u povijest..., pp. 144-145.

[39] I. Škrabalo, op.cit., p. 176.
Stylistic tendencies of modernist films in contemporary Croatian cinema
[40] Not all films with this type of narrative structure are the examples of a modernist style. For example, Eagle $($ Orao, 1990) by Zoran Tadić or Metastases (Metastaze, 200o) by Branko Schmidt are still classical films with reduced classical form. Closer to film Here would be the film The Names of the Cherry (Imena višnje, 2015) by Schmidt.

[41] N. Gilić, Recepcija filmova Larsa von Triera i hrvatski film na prijelazu tisućljeća, in: Komparativna povijest hrvatske književnosti. Zbornik radova IX. Hrvatska književnost XX. stoljeća u prijevodima: emisija i recepcija, eds. C. Pavlović and V. Glunčić-Bužančić, Vinka 2007, p. 389.

[42] T. Šakić, op.cit., pp. 273-274. 
The best way to understand why Here is modernist in nature is to compare it to another film that has a similar mosaic structure but is classical in its scope. For example, A Wonderful Night in Split (Ta divna splitska noć, 2004) by Arsen Anton Ostojić develops its story by following three simultaneous strains of events located in the same setting. At first glance the only thing that connects these three stories and their characters is the space of the narrative (the city of Split) and time (two hours before New Year). But unlike the situation in Here, this film employs a strategy of causally connecting three interrelated fatal destinies of three different characters whose actions across the story are clearly motivated (through the motif of acquiring a drug). So even though the depicted events are loosely connected, they form a clear-cut storyline.

On the other hand, Here never connects the events and characters in a similar way. The only connection between them is reduced to the shared setting in which they are presented, that is, postwar Zagreb (except at the beginning of the film). The film begins with the exposition of the war situation by following a few military characters. In a classical narrative cinema this exposition would be later articulated through, for example, a depiction of the events connected to these same characters. But instead, Ogresta's film only marginally treats these characters in the course of its narrative and focuses more on other characters who are in no way related. That is, the characters depicted in postwar Zagreb (the drug addict Duda, the old man Josip, the alcoholic actor Boris, the former soldier Karlo and the street salesman and student) are not only unrelated to the characters and events in the exposition of the film (except for the soldier Karlo, who appears at the beginning), but are also unrelated to each other. The main orientation of this film is to offer a sketch of their lives and a sketch of a devastated postwar society that can only be interpreted in an indirect way. The film never causally connects the exposition (the war situation) and the later narrative development (the postwar situation) even though the negative aspects of the everyday events of the contemporary characters can be interpreted as an indirect, symbolic consequence of the prior war situation.

Another feature of this film that makes it realist in style is its focus on trivial, everyday, prosaic events and unexceptional, ordinary characters, as well as its manner of presenting them. In the course of this mosaic narrative, the camera often extensively follows the characters in their everyday actions with no apparent narrative conflict or turning point, and also often focuses on chance encounters that will not further the narrative development. These chance encounters are largely followed by the extensive and detailed presentation of events and characters that will not influence the ongoing story and function as isolated narrative segments.

This strategy of treating events or some uninteresting sequence of events in an isolated form will also be an important feature of the psy- 
chological variant of cinematic modernism. The main difference here will be the focus of the narrative. While Ogresta's film never visualizes the subjective, mental states of its characters, focusing instead on the depiction of the surface of their lives, Nola's films will go in a different direction. Nola was in general perceived as a typical representative of the modernist tendency in contemporary Croatian cinema with his films Celestial Bodies (Nebo sateliti, 200o) and Alone (Sami, 2001).[43] He was often understood as a follower of the modernist means of expression found in the 1960 s films of Vatroslav Mimica.[44] Since his type of cinematic modernism resembles Mimica's style through the implementation of complex narrative structure with strong psychological and symbolic elements, some scholars have also described it as an example of high or radical modernism, [45] that is more radical in its poetic expression than the realist type of modernism exemplified by Ogresta's film Here.

In addition to the psychological orientation of these two Nola films, they are also saturated with abstraction (symbolism) and an often permanent narrative ambiguity, both features of cinematic modernism as described by Kovács[46] in relation to the European modernist tradition. For example, in Celestial Bodies we can observe that events surrounding the action of the main character, Jakov Ribar, are treated in an isolated manner. This means that even though the narrative presents different steps in the protagonist's journey, the whole purpose of the journey is non-existent while there is also no causal or any logical transition between phases of this narrative development (since the protagonist just appears in different settings with no prior motivation). Additionally, narrative development in each phase of the journey is not elaborated and does not contribute to the development of the overall story.

The film is also saturated with often-short inserts that looks to be flashes of the protagonist's memories or fantasies, but they could easily be interpreted as extradiegetic inserts that function as authorial commentary with an unexplained narrative status. The film's tendency toward abstraction is visible in the use of different Catholic religious motifs: repeated shots of Jakov walking on water, bathing in water which echoes the motif of baptism, the mentioning of wine, or pigeons using the character as a statue (see Fig. 9). The use of events that are realistically unmotivated is a common strategy in modernist cinema, and is systematically employed in this and other of Nola's films. Another modernist feature of this film is the use of permanent narrative ambiguity, which can be seen in the end of the film. A situation similar to the film's beginning signals that it is equally plausible that the film

[43] B. Kragić, Hrvatski film nakon..., p. 238. N. Gilić, Uvod u povijest..., pp. 157-158.

[44] N. Gilić, Tragovi modernizma 1960-ih u novijem..., p. 422. T. Brlek, Film, kritika, kontekst: "Sami",

"Hrvatski filmski ljetopis" 2002, no. 29, p. 123.
[45] T. Šakić, op. cit., p. 59.

[46] A.B. Kovács, Screening Modernism. European Art Cinema, 1950-1980, Chicago 2007, pp. 62-63. 
started with the story's end or that the situation from the beginning is just repeated in a new (final) situation that can proceed in infinite directions.
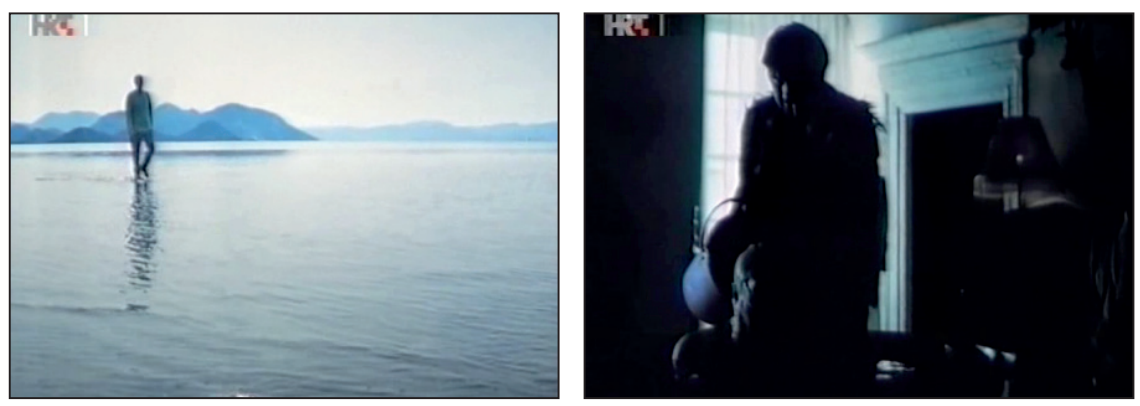

Fig. 9. Celestial Bodies (Nebo sateliti, 200o) by Lukas Nola
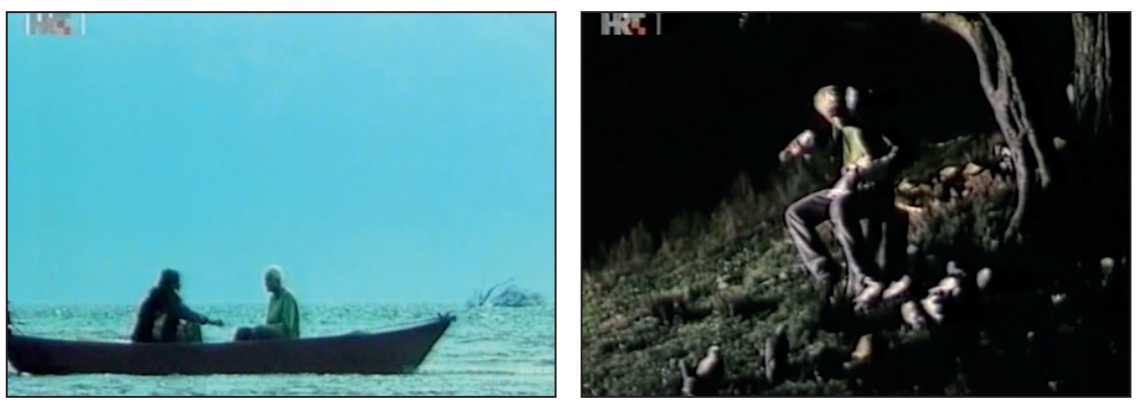

Similar features can be found in another Nola film, Alone. This film is even more radical than Nola's earlier film, but has a crime storyline that will be treated in an unconventional way. The apparent main story of this film is focused on the accidental murder of a young boy caused by the protagonist (played by Leon Lučev). But film only marginally focuses on these events, focusing instead on the psychological state of mind of the protagonist. Even when in later parts of the film we find out that the appearance of a dead boy is not a subjective projection by the protagonist (caused by his guilt), but that the boy has a twin brother, the story is only seemingly resolved. The permanent narrative ambiguity is accentuated at the end of the film when the same actor finds the dead body of the protagonist. It is equally probable that the protagonist also has a twin brother or that he found himself dead, thus advancing the interpretation that there is some psychological paradox at play here. Even the final narrative resolution is advanced in an unconventional way, through a metafilmic strategy. Since the plot is resolved in an ambiguous way, through an unmotivated, deus ex machina strategy, Nola includes the same motif through the appearance of a sign reading "deus ex machina" on a cart being pushed by a minor character in the film (see Fig. 10). In this context, the whole narrative of the film is focused on articulating the subjective state of mind of the protagonist caused by the trauma of losing his daughter (visualized in retrospective shots in one part of the film). Other elements of film's structure also function in this interpretative framework. Unlike its functioning in a classical film, 

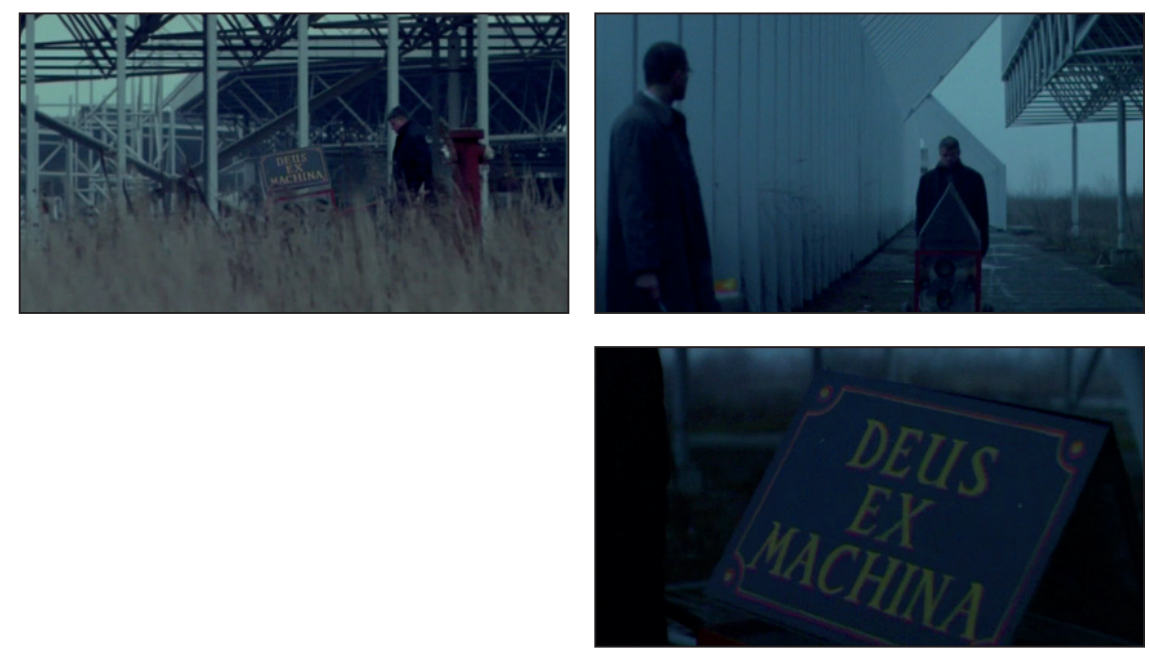

Fig. 10. Alone (Sami, 2001) by Lukas Nola

the images of destructed, empty, post-apocalyptic setting here do not function as a background for advancing the plot, but as an externalized visions of the protagonist's ravaged psyche. Another important element functions in a similar way: the use of ambient film sound. Instead of functioning as background noise for establishing the realist motivation of the presented setting, the noises that the protagonist is recording and listening to on his sound recorder function as a pre-traumatic experience, when his psychological state was stable and not ravaged by the trauma.

Since the film as a whole is structured in this manner, Nola systematically employs unmotivated chain of events that cannot be interpreted in a clear-cut way. Thus, when he presents the viewer with a scene of a sexual encounter between the protagonist and his girlfriend during which they eat chicken feathers and lick a blood-like substance, there is no narrative (realistic or compositional) framework into which these events can be contextualized (see Fig. 11). These surrealistic shots only advance the general modernist aspirations of the film.
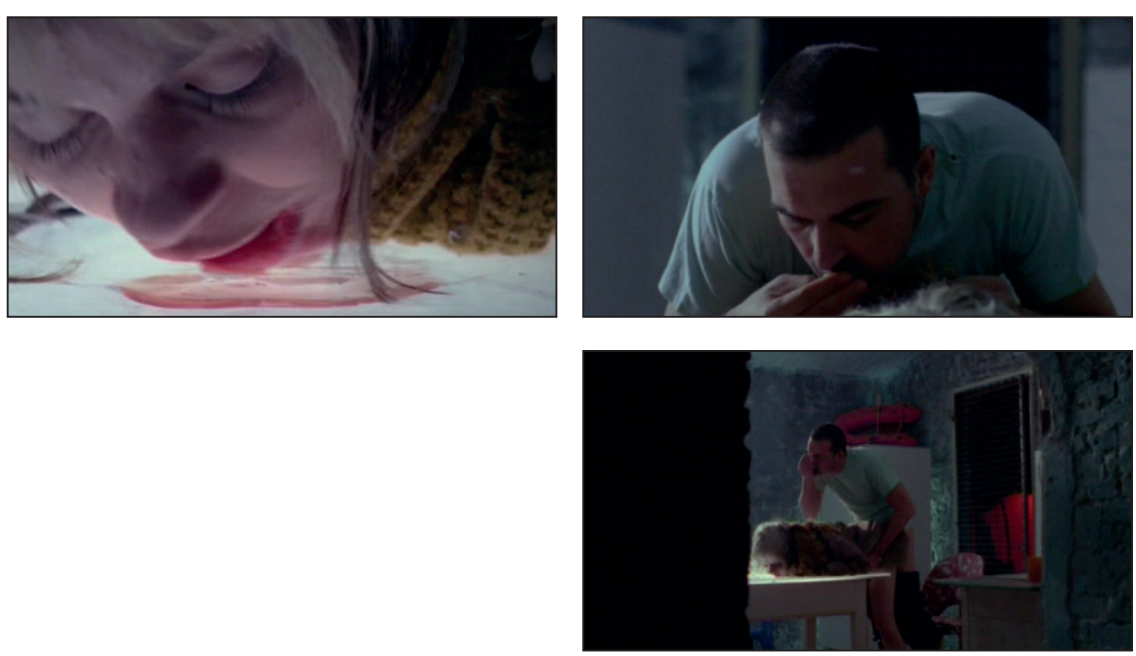

Fig. 11. Alone (Sami, 2001) by Lukas Nola 
In conclusion, we can only observe that contemporary Croatian cinema exploited a stylistic framework that was already advanced in the Yugoslav period, and that different classical and modernist tendencies found their articulation in the works by Ogresta, Nola, Matanić, Sviličić and others not analyzed in this paper. And even though these stylistic orientations were partly determined by the changed political, social and/or cultural situation of the post-1990s, the films still relied on the stylistic heritage of earlier authors and their various means of cinematic expression.

Bordwell D., Staiger J., Thompson K., The Classical Hollywood Cinema. Film Style \& Mode of Production to 1960, London 1999

Brlek T., Film, kritika, kontekst: "Sami”, "Hrvatski filmski ljetopis" 2002, no. 29, pp. 123-129

Gilić N., Dokumentarističke tehnike otpora u igranom filmu i rani filmovi Tomislava Radića, in: Otpor. Subverzivne prakse u hrvatskome jeziku, književnosti $i$ kulturi, eds. T. Pišković and T. Vuković, Zagreb 2014. Zagrebačka slavistička škola, pp. 9-20

Gilić N., Filmski medij, in: Uvod u medije, ed. Z. Peruško, Zagreb 2011. Hrvatsko sociološko društvo, pp. 87-108

Gilić N., New Croatian Cinema: Literature and Genre in the Post-Yugoslav Era, in: Small Cinemas in Global Markets, eds. L. Giukin, J. Falkowska and D. Desser, New York, London 2015, pp. 151-169

Gilić N., Recepcija filmova Larsa von Triera i hrvatski film na prijelazu tisućljeća, in: Komparativna povijest hrvatske književnosti. Zbornik radova IX. Hrvatska književnost XX. stoljeća u prijevodima: emisija i recepcija, eds. C. Pavlović and V. Glunčić-Bužančić, Split 2007, pp. 380-395

Gilić N., Tragovi modernizma 1960-ih u novijem hrvatskom igranom filmu, in: Komparativna povijest hrvatske književnosti. Zbornik radova XII. Istodobnost raznodobnog. Tekst i povijesni ritmovi, eds. C. Pavlović, V. Glunčić-Bužančić and A. Meyer-Fraatz, Split-Zagreb 2010. Odsjek za komparativnu književnost Filozofskog fakulteta Sveučilišta u Zagrebu, pp. 420-429

Gilić N., Uvod u povijest hrvatskog igranog filma, Zagreb 2010

Gray B., Stylistics: The end of a tradition, "The Journal of Aesthetics and Art Criticism" 1973, no. 4 (31), pp. 501-512

Hirschfeld M., Croatian cinematic identity: A Balkan entity or a European individual?, "Studies in Eastern European Cinema" 2011, no. 1 (2), pp. 21-36

Kovács A.B., Screening Modernism. European Art Cinema, 1950-1980, Chicago 2007

Kragić B., Hrvatski film nakon 1990. - prijedlog stilske klasifikacije, "Sarajevske sveske" 2008, no. 19-20, pp. 235-241

Kragić B., Izazovi "Amerike" u hrvatskom filmu i pisanju o filmu - esej o postupnoj realizaciji naslovne metafore, in: Prešućeno, zabranjeno, izazovno u hrvatskoj književnosti i kazalištu, eds. N. Batušić et al., Split 2007, pp. 527-536

Kragić B., Klasični stil u historiografijama hrvatskoga filma, in: 60 godina Festivala igranoga filma u Puli i hrvatski film, eds. Ni. Gilić and Z. Vidačković, Zagreb 2013, pp. 81-99

Kragić B., Neke tendencije klasičnoga filma: tri eseja, Zagreb 2017 
Laćan S., Concealing, revealing, and coming out: lesbian visibility in Dalibor Matanićs Fine Dead Girls and Dana Budisavljevićs Family Meals, "Studies in European Cinema” 2015, no. 3 (12) pp. 229-245, <http://dx.doi.org/10.1080/17411548. 2015.1094260> [accessed: 23.01.2017]

Lučić K., Filmski stil: teorijski pristup i stilistika hrvatskog igranog filma, Zagreb 2017

Lučić K., The representation of minorities in contemporary Croatian film, "Umjetnost riječi” 2016, no. 3-4 (60), pp. 231-260

Moss K., Three Gay Films from Former Yugoslavia, in: American Contributions to the 14th International Congress of Slavists, Ohrid, September 2008. Vol. 2: Literature, ed. D.M. Bethea, Bloomington 2008, pp. 125-138

Pavičić J., "Cinema of normalization": changes of stylistic model in post-Yugoslav cinema after the 1990s, "Studies in Eastern European Cinema" 2010, no. 1 (1), pp. 43-56

Pavičić J., Trendovi hrvatskog filma, “Hrvatski filmski ljetopis” 1997, no. 11, pp. 3-8

Pavičić J., Usiljena učitavanja: filmska i književna kritika o hrvatskoj žanrovskoj proizvodnji, "Hrvatski filmski ljetopis" 2000, no. 22, pp. 35-37

Robinson J.M., General and Individual Style in Literature, "The Journal of Aesthetics and Art Criticism" 1984, no. 2 (43), pp. 147-158

Robinson J.M., Style and personality in the literary work, "The Philosophical Review" 1985, no. 2 (94), pp. 227-247

Rucker-Chang S.T., Filmic representations of the Chinese presence in Serbia, Croatia, Bosnia and Slovenia, in: Chinese Migrants in Russia, Central Asia and Eastern Europe, eds. F.B. Chang and S.T. Rucker-Chang, London-New York 2012, pp. 199-220

Šakić T., Modernizam u hrvatskom igranom filmu, Zagreb 2016

Simić M., Forenzičarka feministica u akciji!, "Hrvatski filmski ljetopis” 2006, no. 45, pp. 64-69

Škrabalo I., Hrvatska filmska povijest ukratko (1896-2006), Zagreb 2008

Turković H., Film: zabava, žanr, stil, Zagreb 2005

Turković H., Filmska opredjeljenja, Zagreb 1985

Turković H., Nacrt filmske genologije, Zagreb 2010

Turković H., Majcen V., Hrvatska kinematografija: povijesne značajke, suvremeno stanje, filmografija (1991-2002), Zagreb 2003

Vidan A., Narativi drugosti i krize u južnoslavenskim filmovima novog milenija, in: Komparativni postsocijalizam: slavenska iskustva, ed. M. Kolanović, Zagreb 2013, pp. 331-350

Vidan A., Spaces of ideology in South Slavic films, "Studies in Eastern European Cinema” 2011, no. 2 (2), pp. 173-192

Vojković S., Subjektivnost u novom hrvatskom filmu: kritičkonaratološki pristup, "Hrvatski filmski ljetopis" 2006, no. 46, pp. 23-31

100 Minutes of Glory (100 minuta Slave), dir. Dalibor Matanić, 2004

F I L MO G R A P H Y A Story from Croatia (Priča iz Hrvatske), dir. Krsto Papić, 1991

A Wonderful Night in Split (Ta divna splitska noć), dir. Arsen Anton Ostojić, 2004 Accidental Life (Slučajni život), dir. Ante Peterlić, 1969

Alone (Sami), dir. Lukas Nola, 2001

Alphabet of Fear (Abeceda straha), dir. Fadil Hadžić, 1961

Armin, dir. Ognjen Sviličić, 2007

Behind the Glass (Iza stakla), dir. Zrinko Ogresta, 2008

Borders (Razmeđa), dir. Krešo Golik, 1973 
Cashier Wants to Go to the Seaside (Blagajnica hoće ići na more), dir. Dalibor Matanić, 2000

Celestial Bodies (Nebo sateliti), dir. Lukas Nola, 2000

Countess Dora (Kontesa Dora), dir. Zvonimir Berković, 1993

Eagle (Orao), dir. Zoran Tadić, 1990

Fine Dead Girls (Fine mrtve djevojke), dir. Dalibor Matanić, 2002

Here (Tu), dir. Zrinko Ogresta, 2003

I Have Two Mothers and Two Fathers (Imam 2 mame i 2 tate), dir. Krešo Golik, 1968

Kotlovina, dir. Tomislav Radić, 2011

Metastases (Metastaze), dir. Branko Schmidt, 2009

Monday or Tuesday (Ponedjeljak ili utorak), dir. Vatroslav Mimica, 1966

Red Dust (Crvena prašina), dir. Zrinko Ogresta, 1999

Sorry for Kung Fu (Oprosti za kung fu), dir. Ognjen Sviličić, 2004

The Girl and the Oak (Djevojka i hrast), dir. Krešo Golik, 1955

The Names of the Cherry (Imena višnje), dir. Branko Schmidt, 2015

The Stone Gate (Kamenita vrata), dir. Ante Babaja, 1992

The Third Woman (Treća žena), dir. Zoran Tadić, 1997

Vegetarian Cannibal (Ljudožder vegetarijanac), dir. Branko Schmidt, 2012

Washed Out (Isprani), dir. Zrinko Ogresta, 1995

What Iva Recorded (Što je Iva snimila 21. listopada 2003.), dir. Tomislav Radić, 2005 